Article

\title{
Photochemical Oxidation Process of Copper from Electroplating Wastewater: Process Performance and Kinetic Study
}

\author{
Aji Prasetyaningrum *, Teguh Riyanto $\mathbb{D}$, Mohamad Djaeni $\mathbb{D}^{\circ}$ and Widayat Widayat \\ Department of Chemical Engineering, Faculty of Engineering, Diponegoro University, Jl. Prof. Soedarto S.H., \\ Tembalang, Semarang 50275, Indonesia; teguh_ryt@student.undip.ac.id (T.R.); \\ moh.djaeni@live.undip.ac.id (M.D.); widayat@live.undip.ac.id (W.W.) \\ * Correspondence: aji.prasetyaningrum@che.undip.ac.id; Tel.: +62-24-746-0058
}

Received: 21 September 2020; Accepted: 8 October 2020; Published: 12 October 2020

check for updates

\begin{abstract}
An investigation of the process of ozone combined with ultraviolet radiation has been carried out in order to establish the kinetics for photochemical oxidation of copper $(\mathrm{Cu})$ from electroplating wastewater. The effects of operating parameters, including initial $\mathrm{Cu}$ concentration, ozone dosage, $\mathrm{UV}$ irradiation intensity, and $\mathrm{pH}$ value on the photochemical oxidation of $\mathrm{Cu}$ have been studied comprehensively. The $\mathrm{Cu}$ concentration during the reaction was identified using atomic absorption spectroscopy (AAS) method. The solid product was analyzed using X-ray diffraction (XRD) and scanning electron microscope-energy-dispersive X-ray (SEM-EDX) methods. It was found that the UV-Ozone process has high performance on $\mathrm{Cu}$ removal compared to UV and Ozone processes due to the high production rate of $\mathrm{HO} \bullet$ radicals. It was also found that the solid product from the UV-Ozone process was $\mathrm{CuO}$ monoclinic crystal phase. The initial $\mathrm{Cu}$ concentration, ozone dosage, and $\mathrm{pH}$ value were significantly affected the $\mathrm{Cu}$ removal efficiency. On the other hand, the UV irradiation intensity was not significant; however, it has responsibility in promoting the ozone photolysis. The kinetics model for the photochemical oxidation of $\mathrm{Cu}$ was established following the first-order kinetic model. Furthermore, the reaction mechanism was also developed.
\end{abstract}

Keywords: photochemical oxidation; $\mathrm{Cu}$; kinetics; ozone; ultraviolet irradiation; advanced oxidation process

\section{Introduction}

Heavy metals have become a global issue of environmental and public health concern because of their toxicity and bioaccumulation in the human body and food chain [1]. The effects of urbanization and industrialization cause an increase in heavy metal pollution to the environment [2]. High toxicity and nonbiodegradability of heavy metals caused a number of environmental problems [3]. The accumulation of heavy metals in the atmosphere is responsible for both natural and anthropogenic activities [4]. Copper $(\mathrm{Cu})$, as an essential trace element, is required by biological systems for the activation of some enzymes during photosynthesis. However, at higher concentrations, it shows harmful effects on the human body. Continuous exposure may lead to kidney damage and even death. $\mathrm{Cu}$ is also toxic to a variety of aquatic organisms even at very low concentrations. Mining, metallurgy, and industrial applications are the major sources of $\mathrm{Cu}$ exposure in the environment [5].

There were several techniques for the treatment of industrial wastewater containing heavy metals, including chemical precipitation, ion exchange, coagulation-flocculation, flotation, membrane filtration, electrochemical treatment, magnetic separation and purification, biosorption, and nanotechnology [6]. Advanced oxidation processes (AOPs) are promising, efficient, and environmentally friendly methods 
for the removal of wastewater contaminants [7]. The AOPs can be photochemical AOP, sonochemical AOP, and electrochemical AOP [7]. The basic principles of AOPs are the in situ generations of hydroxyl radicals $(\mathrm{HO} \bullet)$ during the oxidation process. The hydroxyl radicals can be produced from hydrogen peroxide $\left(\mathrm{H}_{2} \mathrm{O}_{2}\right)$, ozone, photocatalysis, or oxidants in combination with ultraviolet (UV) radiation [8].

Ozone is an active oxidant, which is commercially available and widely used in municipal water treatment and wastewater treatment. Moreover, wastewater treatment with ozone is an environment-friendly method. The pollutants such as color, odor, and microorganisms are oxidized directly without generating harmful chlorinated by-products or substantial residues [9]. In order to increase the effectivity of the ozonation process, it is necessary to combine the ozone process with another process that can increase the reaction efficiency between ozone and pollutant. The promising process is the combination of ozone and UV irradiation that could enhance the production of hydroxyl radicals (HO•) as the main oxidant compounds in AOP [10]. The combination of UV-Ozone process has been reported as a promising process for $\mathrm{HO} \bullet$ radical formation [11-13]. Therefore, the oxidation process could be accelerated. Based on this characteristic, the combination of UV-Ozone process has a potential option for wastewater treatment [14].

Since the UV-Ozone process has high beneficial result in wastewater treatment, it is important to investigate this process comprehensively. However, the utilization of the UV-Ozone process for $\mathrm{Cu}$ removal from electroplating wastewater is still limited. Therefore, the comparison of UV, Ozone, and UV-Ozone processes is investigated in this study. Furthermore, the effect of several operating parameters, including initial $\mathrm{Cu}$ concentration, ozone dosage, $\mathrm{UV}$ irradiation intensity, and $\mathrm{pH}$ value, on the $\mathrm{Cu}$ removal process from electroplating wastewater through photochemical (UV-Ozone) oxidation process is also comprehensively studied. In addition, the kinetic study of this process is important for scale-up processing. The study of the kinetics of wastewater treatment with a combination of UV-Ozone process for organic compound degradation has been investigated by several previous researchers $[15,16]$. However, to the best of our knowledge, there are no previous studies concerning the kinetic study in $\mathrm{Cu}$ removal from electroplating wastewater by UV-Ozone process. Some previous studies on $\mathrm{Cu}$ or other metals removal from wastewater are focused on investigating the process parameters affecting the process $[17,18]$. Based on these understandings, in this study, the kinetic models of the $\mathrm{Cu}$ removal process are investigated in order to determine the order of the kinetic rate. In addition, the relation of operating parameters with the kinetic parameter is also investigated comprehensively. Extendedly, the correlation between process parameters and kinetic parameter is developed. This correlation accommodates the prediction of the kinetic parameter on different process conditions. Therefore, the kinetic rate of $\mathrm{Cu}$ removal through photochemical oxidation can be easily predicted. The possible reaction mechanism of $\mathrm{Cu}$ removal using UV-Ozone process is also addressed in this study.

\section{Materials and Method}

\subsection{Materials}

This experiment was carried out using synthetic wastewater with an initial copper concentration of $145.73 \mathrm{mg} / \mathrm{L}$. The initial concentration of samples was prepared based on the composition of copper from industrial electroplating wastewater from a plant located at Juwana, Pati, Central of Java Indonesia which has copper concentration of $145.73 \mathrm{mg} / \mathrm{L}$. Synthesized wastewater with varying copper concentrations $(145.73,72.86$, and $36.9 \mathrm{mg} / \mathrm{L})$ was prepared by dissolving the corresponding amount of $\mathrm{CuSO}_{4} \cdot 5 \mathrm{H}_{2} \mathrm{O}$ (>98\%, Merck) in deionized (DI) water. The initial $\mathrm{pH}$ value of the solution was adjusted using $\mathrm{HCl}$ (37\%, Merck) and $\mathrm{NaOH}$ (>98\%, Merck).

\subsection{Experimental System Setup}

The experimental study on photochemical oxidation of copper by ozone combined with UV irradiation was conducted in a bubble column reactor made of borosilicate glass. The reactor was 
equipped with a low-pressure mercury UV light (Philips-TUV 8 Watt, Koninklijke Philips N.V., Amsterdam, The Netherlands) with main emission line at $253.7 \mathrm{~nm}$. Ozone gas generated from ozone generator type dielectric barrier discharge (Dipo Technology, Diponegoro University, Jawa Tengah, Indonesia) connected to reactors UV-Ozone (Figure 1). The ozone dosage was varied at 5 , 10 , and $15 \mathrm{mg} / \mathrm{h}$. The UV-Ozone photoreactor was performed under a semibatch condition reaction. The reactor was an open-top cylindrical tank with a fixed top suspension with a low-pressure mercury UV light. UV irradiation intensity was varied at 20,40, and $60 \mathrm{~mW} / \mathrm{cm}^{2}$. The UV irradiation intensity was adjusted by varying the number of UV light. The UV irradiation intensity was measured using a J-225 Black Ray intensity meter (Analytik Jena US, Upland, CA, USA). A fritted glass diffuser was placed at the bottom of the reactor to allow the continuous injection of ozonized gas. Ozone was produced from the air, which flows into the ozone generator. The reaction was adjusted for different time periods (i.e., 10, 20, 30, 40, 50, and $60 \mathrm{~min}$ ) and initial $\mathrm{pH}(3,6,8$, and 10) during UV-Ozone treatment. All oxidation reaction processes were conducted at room temperature and atmospheric pressure. The initial $\mathrm{pH}$ was adjusted using $\mathrm{NaOH}$ and $\mathrm{HCl}$ solutions.

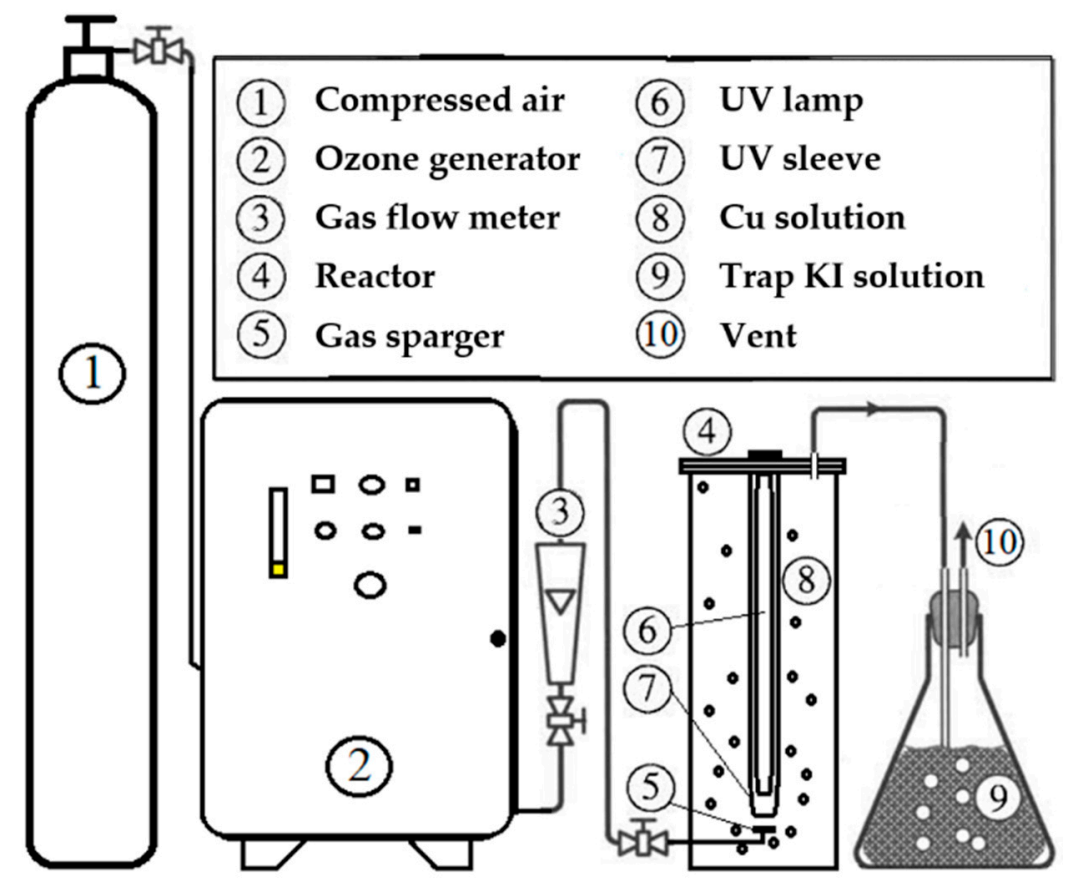

Figure 1. Schematic diagram of UV-Ozone treatment equipment.

\subsection{Analytical Methods}

A pH meter analyzer (EZDO PH-5011A) was used during the procedure for assessing the $\mathrm{pH}$ of the response solution. An atomic absorption spectroscopy (AAS) (Shimadzu AA 6300, Kyoto, Japan) was used to analyze $\mathrm{Cu}$ concentration and wastewater samples. Even though the UV-VIS method can be used to analyzed $\mathrm{Cu}$ concentration in the solutions, the shift on maximum wavelength absorbance at different $\mathrm{pH}$ could affect the inaccuracy in the measurement [19-21] since we variated the $\mathrm{pH}$ as one of the process parameters investigated. The solid product was also analyzed using X-ray diffraction (XRD) (Shimadzu XRD-7000, Kyoto, Japan) method. The $\mathrm{Cu} \mathrm{K} \alpha$ radiation $(\lambda=1.54 \AA$ ) was operated at $30 \mathrm{~mA}$ and $30 \mathrm{kV}$. The diffraction patterns were generated at $2 \theta$ angle ranges of $20-70^{\circ}$ with a scanning speed of $4^{\circ} \mathrm{min}^{-1}$. The surface morphology and metal oxide composition of the solid product were analyzed using scanning electron microscope-energy dispersive X-ray (SEM-EDX) (SEM-EDX JEOL JSM-6510LA, Tokyo, Japan) method. The removal efficiency was calculated using Equation (1), when $\eta$ 
is the $\mathrm{Cu}$ removal efficiency $(\%), C_{0}$ is the initial $\mathrm{Cu}$ concentration $(\mathrm{mg} / \mathrm{L})$, and $C_{t}(\mathrm{mg} / \mathrm{L})$ is the $\mathrm{Cu}$ concentration at time $t$.

$$
\eta(\%)=\frac{C_{0}-C_{t}}{C_{0}} \times 100
$$

\section{Results and Discussions}

\subsection{Comparation of UV, Ozone. and Combination UV-Ozone}

In order to study the different effects of UV, Ozone, and UV-Ozone combination processes on $\mathrm{Cu}$ removal from electroplating wastewater, these three processes are compared. The result is shown in Figure 2.

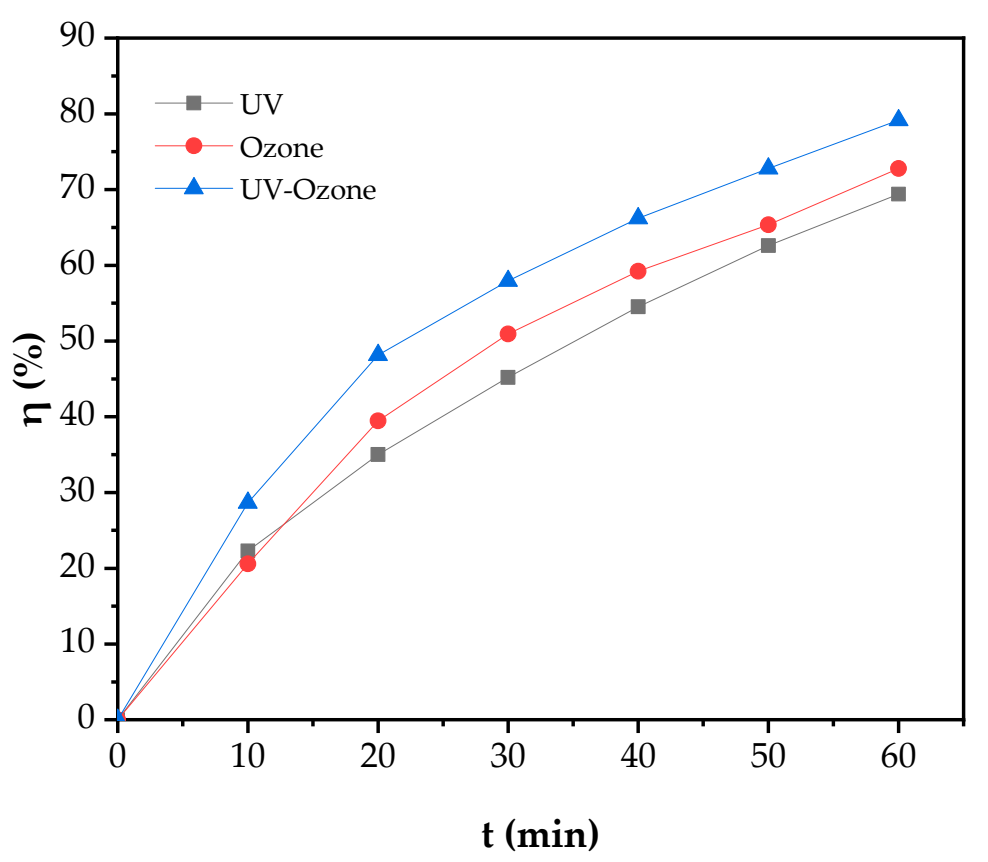

Figure 2. Comparison of UV, Ozone, and UV-Ozone combination processes.

Figure 2 depicted the comparison of UV, Ozone, and combined UV-Ozone treatment on $\mathrm{Cu}$ removal efficiency from electroplating wastewater. As can be seen, at $60 \mathrm{~min}$ of reaction, the $\mathrm{Cu}$ removal efficiency obtained from the UV irradiation process is $69.08 \%$, whereas the $\mathrm{Cu}$ removal efficiency obtained from Ozone treatment is $72.64 \%$. Interestingly, the $\mathrm{Cu}$ removal efficiency can be increased up to $78.8 \%$ when the UV and Ozone processes are combined. This high $\mathrm{Cu}$ removal efficiency can be obtained by the enhancement of hydroxyl radicals $(\mathrm{HO} \bullet)$ during the combination of UV and Ozone processes. As reported by Hanela et al. [10], the combination of UV irradiation and ozone could enhance the production of hydroxyl radicals; therefore, the oxidation process could be accelerated. Furthermore, it is suggested that the combination of UV irradiation and Ozone treatment can increase the $\mathrm{Cu}$ removal efficiency in the $\mathrm{Cu}$ removal process from electroplating wastewater. It is true since the mechanism of $\mathrm{Cu}$ oxidation through AOP is initiated by the presence of HO• radicals. Equations (2) and (3) represent the oxidation process of $\mathrm{Cu}$ through AOP. As can be seen in Equation (2), the $\mathrm{Cu}^{2+}$ ion is oxidized by $\mathrm{HO} \bullet$ radicals producing solid $\mathrm{CuO}$ and water molecules.

$$
\begin{gathered}
\mathrm{Cu}^{2+}+2 \mathrm{HO} \bullet \\
\rightarrow \mathrm{CuO}_{\downarrow}+\mathrm{H}_{2} \mathrm{O} \\
\mathrm{Cu}^{2+}+\mathrm{O}_{3} \rightarrow \mathrm{CuO} \downarrow+\mathrm{O}_{2} .
\end{gathered}
$$

Based on Equation (2), the important thing in Cu removal through AOP is the presence of HO• radicals. Therefore, it is suggested that the process of producing more $\mathrm{HO} \bullet$ radicals is the preferred 
process. As can be seen in Figure 2, the $\mathrm{Cu}$ removal efficiency obtained by the UV irradiation process is the lowest compared to the other processes. It is true since the UV irradiation process without the presence of ozone in the system only produces $\mathrm{HO} \bullet$ radicals through the photolysis of the $\mathrm{H}_{2} \mathrm{O}$ molecule [12,22]. The photolysis of the $\mathrm{H}_{2} \mathrm{O}$ molecule by UV irradiation is shown in Equation (4) [12]. The other possible mechanisms in HO• production through the UV irradiation process are shown in Equations (5) and (6) [23].

$$
\begin{gathered}
\mathrm{H}_{2} \mathrm{O}+h v \rightarrow \mathrm{HO} \bullet+\mathrm{H} \bullet \\
\mathrm{H}_{2} \mathrm{O}+h v \rightarrow \mathrm{H}_{2} \mathrm{O}^{*} \\
\mathrm{H}_{2} \mathrm{O}^{*}+h v \rightarrow \mathrm{HO} \bullet+H \bullet .
\end{gathered}
$$

For the Ozone treatment, as depicted in Figure 2, the $\mathrm{Cu}$ removal efficiency is higher than the $\mathrm{Cu}$ removal efficiency obtained by the UV irradiation process. This is due to the fact that the Cu oxidation through Ozone treatment can be initiated by $\mathrm{HO} \bullet$ radicals and directly oxidized by the ozone molecule (Equation (3)). These two reactions occurred in Ozone treatment, therefore; the Cu removal efficiency obtained by Ozone treatment is higher than obtained by UV treatment. The chemical reaction of HO• radicals formation through Ozone treatment is shown in Equation (7) [12].

$$
3 \mathrm{O}_{3}+\mathrm{H}_{2} \mathrm{O} \rightarrow 2 \mathrm{HO} \bullet+4 \mathrm{O}_{2}
$$

As mentioned before, the highest $\mathrm{Cu}$ removal efficiency is obtained by the UV-Ozone process due to the high $\mathrm{HO} \bullet$ radical formation during the combination of the UV irradiation process and the Ozone process. Besides, the presence of ozone can also increase the oxidation process due to the direct oxidation process. The formation of $\mathrm{HO} \bullet$ radicals in the UV-Ozone process has been widely reported. Some proposed $\mathrm{HO} \bullet$ radical formation during the UV-Ozone process follow the reaction mechanism as described in Equations (8)-(10) [12,24]:

$$
\begin{gathered}
\mathrm{O}_{3}+\mathrm{H}_{2} \mathrm{O}+\mathrm{hv} \rightarrow \mathrm{O}_{2}+\mathrm{H}_{2} \mathrm{O}_{2} \\
\mathrm{H}_{2} \mathrm{O}_{2}+h v \rightarrow 2 \mathrm{HO} \bullet \\
\mathrm{H}_{2} \mathrm{O}_{2}+\mathrm{H}_{2} \mathrm{O} \rightarrow \mathrm{H}_{3} \mathrm{O}^{+}+\mathrm{HO}_{2}^{-} \\
\mathrm{O}_{3}+\mathrm{HO}_{2}^{-} \rightarrow \mathrm{HO}^{-}+\mathrm{O}_{2}+\mathrm{O}_{2} \bullet \\
\mathrm{O}_{3}+\mathrm{O}_{2} \bullet \rightarrow \mathrm{O}_{2}+\mathrm{O}_{3} \bullet \\
\mathrm{O}_{3} \bullet+\mathrm{H}_{2} \mathrm{O} \rightarrow \mathrm{HO} \bullet+\mathrm{HO}^{-}+\mathrm{O}_{2} \\
\mathrm{O}_{3}+\mathrm{H}_{2} \mathrm{O}_{2} \rightarrow \mathrm{HO} \bullet+\mathrm{O}_{2}+\mathrm{HO}_{2} \bullet \\
\mathrm{H}_{2} \mathrm{O}_{2}+\mathrm{HO} \bullet \rightarrow \mathrm{HO}_{2} \bullet+\mathrm{H}_{2} \mathrm{O} .
\end{gathered}
$$

As can be seen, in the UV-Ozone process, an additional oxidant, $\mathrm{H}_{2} \mathrm{O}_{2}$, is generated through $\mathrm{O}_{3}$ photolysis (Equation (8)) [12]. $\mathrm{O}_{3}$ reacts with $\mathrm{H}_{2} \mathrm{O}$ to form $\mathrm{H}_{2} \mathrm{O}_{2}$ under UV irradiation. This oxidant can produce more $\mathrm{HO} \bullet$ radicals. $\mathrm{H}_{2} \mathrm{O}_{2}$ absorbs $\mathrm{UV}$ light to generate $\mathrm{HO} \bullet$ radicals. It should be noted that this process can occur only at the presence in light sources with wavelength below $300 \mathrm{~nm}$ [17]. Therefore, UV light is preferred rather than visible light in this study. By this fact, the Cu removal efficiency can be increased following the reaction shown in Equation (2) in the combination of UV and Ozone process. This finding is in accordance with several previous studies. In dyehouse wastewater subjected to the combination of UV-Ozone treatment, a significant color reduction, up to $98.3 \%$, was obtained [13]. For another reason, Bes-Piá et al. [11] studied the UV-Ozone process for textile wastewater treatment. They reported that the combination of UV irradiation with ozone could significantly reduce the operating time to reach the same COD removal efficiency. 


\subsection{Characterization of the Solid Product}

As reported in Section 3.1, the UV-Ozone process has the highest Cu removal efficiency compared to the other processes. The $\mathrm{Cu}$ removal through this process produces a solid product that is proposed as $\mathrm{CuO}$, as shown in Equations (2) and (3). In order to prove that the solid product is $\mathrm{CuO}$, the solid product was analyzed. Figure 3 shows the XRD pattern of the solid product obtained from the UV-Ozone process. Based on Figure 3, the characteristic peaks appear at $2 \theta$ of $32.54^{\circ}, 35.56^{\circ}, 38.74^{\circ}$, $48.68^{\circ}, 53.62^{\circ}, 58.16^{\circ}, 61.62^{\circ}, 66.12^{\circ}$, and $68.12^{\circ}$. These peaks correspond to the $\mathrm{CuO}$ (tenorite phase) according to the JCPDS card number 96-900-8962. These also indicate that the formation of monoclinic crystal structure [25]. On the other hand, several studies reported that two peaks at $2 \theta=35.6^{\circ}(002)$ and $2 \theta=38.8^{\circ}$ (111) observed in the diffraction patterns are ascribed to the formation of the $\mathrm{CuO}$ (space group C2/c) monoclinic crystal phase [26,27]. In this study, these peaks appear at $2 \theta=35.56^{\circ}$ and $2 \theta=38.74^{\circ}$. Therefore, it is confirmed that the solid product produced from the UV-Ozone process is $\mathrm{CuO}$ in the monoclinic crystal phase.

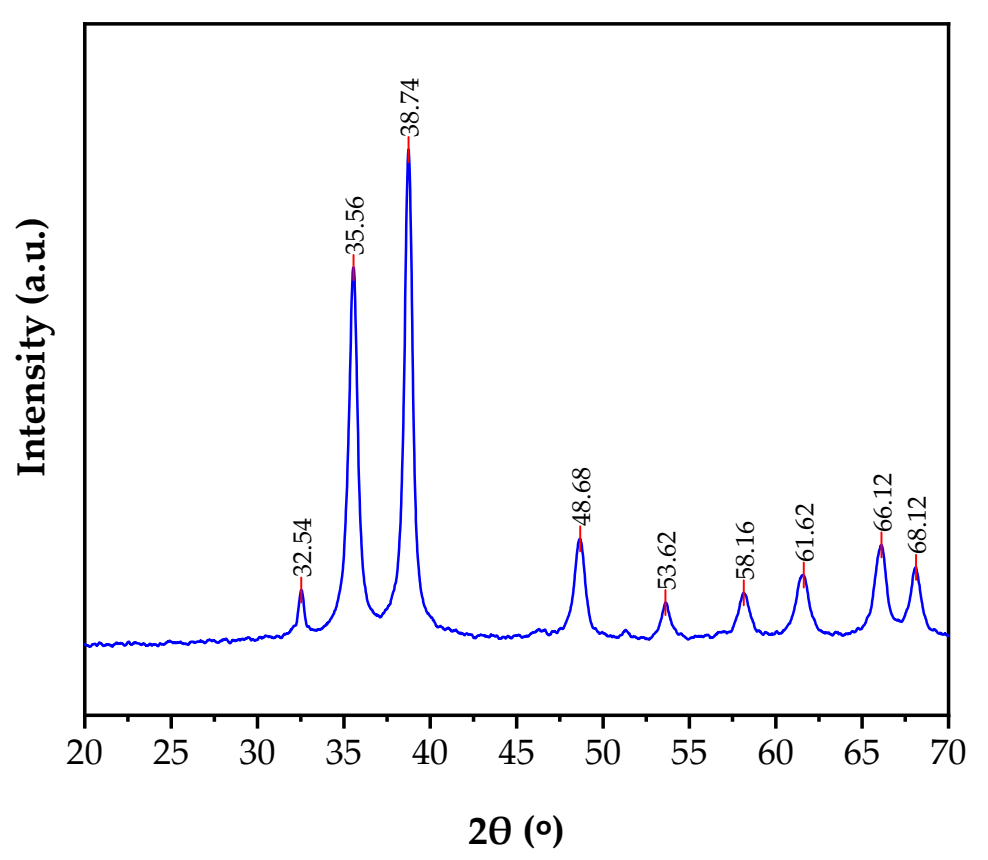

Figure 3. XRD pattern of the solid product obtained from UV-Ozone process.

The morphology and the metal oxide composition of the solid product from the UV-Ozone process are identified using SEM analysis. Based on the result of SEM-EDX analysis (Figure 4a), it is confirmed that the most metal oxide present in the solid product is $\mathrm{CuO}$. The $\mathrm{CuO}$ content detected by SEM-EDX analysis in the solid product is $83.52 \%$. The other components detected may be produced from the impurities in the wastewater. However, it is confirmed that the solid product is $\mathrm{CuO}$. Figure $4 \mathrm{~b}$ shows the appearance of the solid product surface (right) and the model of the $\mathrm{CuO}$ monoclinic crystal structure (left). As can be seen, the surface morphology of the $\mathrm{CuO}$ is agglomerated nanorods. Manyasree et al. [28] reported that the surface morphology of the $\mathrm{CuO}$ nanoparticle, which was synthesized from copper sulfate and sodium hydroxide through the coprecipitation process, is a flower-shaped structure. 


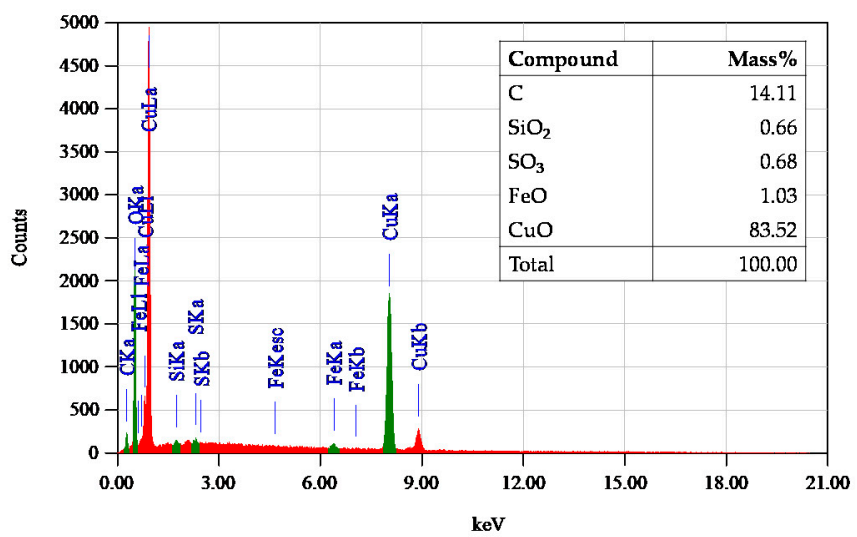

(a)

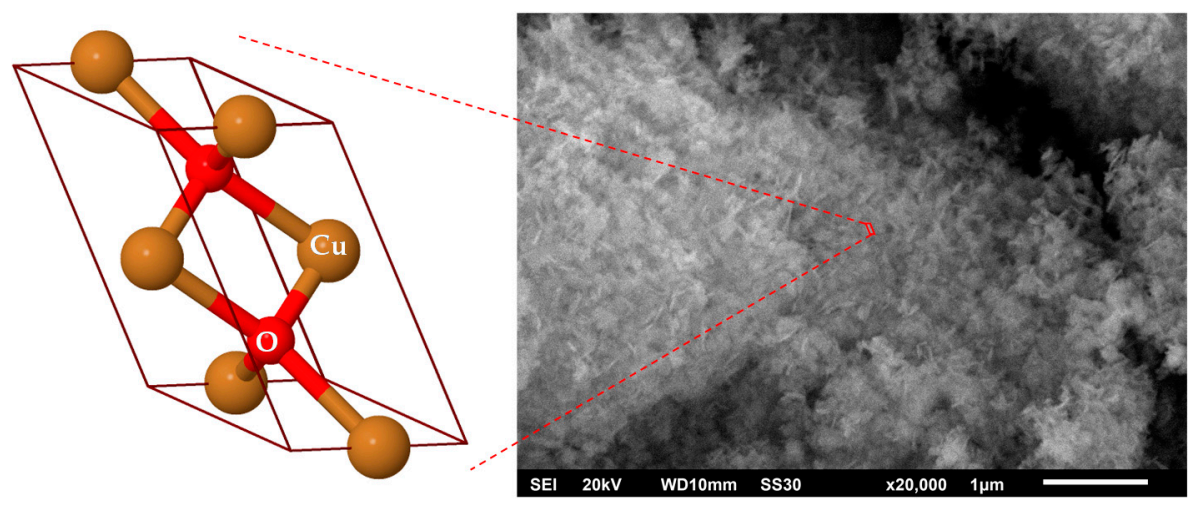

(b)

Figure 4. Composition of metal oxide in the solid product (a) and surface morphology (right) and crystal structure model (left) of the solid product (b).

\subsection{The Effect of Operating Parameters}

\subsubsection{Effect of Initial Concentration}

In order to study the effect of the initial $\mathrm{Cu}$ concentration, the photochemical oxidation process was conducted with the variation of the initial $\mathrm{Cu}$ concentration. The initial $\mathrm{Cu}$ concentration was varied at $145.73,72.86$, and $36.9 \mathrm{mg} / \mathrm{L}$. The monitored parameter is the $\mathrm{Cu}$ removal efficiency. The effect of initial $\mathrm{Cu}$ concentration on $\mathrm{Cu}$ removal efficiency is depicted in Figure 5.

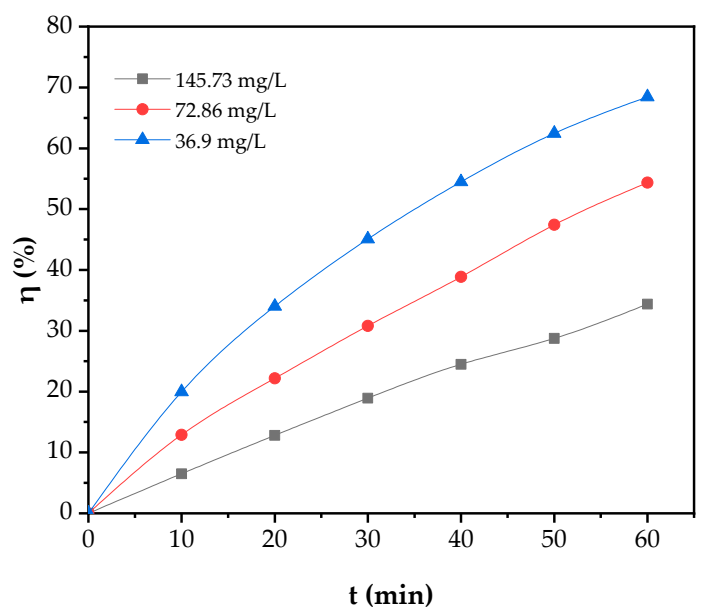

Figure 5. Effect of initial $\mathrm{Cu}$ concentration on $\mathrm{Cu}$ removal efficiency through photochemical process. 
As can be seen in Figure 5, the $\mathrm{Cu}$ removal efficiency is significantly affected by the initial $\mathrm{Cu}$ concentration. During the oxidation process for $60 \mathrm{~min}$, the $\mathrm{Cu}$ removal efficiency obtained at the initial $\mathrm{Cu}$ concentration of $145.73 \mathrm{mg} / \mathrm{L}$ is $34.39 \%$, the Cu removal efficiency obtained at the initial $\mathrm{Cu}$ concentration of $72.86 \mathrm{mg} / \mathrm{L}$ is $54.36 \%$, while the $\mathrm{Cu}$ removal efficiency obtained at the initial $\mathrm{Cu}$ concentration of $36.9 \mathrm{mg} / \mathrm{L}$ is $68.46 \%$. Based on these results, it is suggested that the initial $\mathrm{Cu}$ concentration has a significant effect on the $\mathrm{Cu}$ removal efficiency in the $\mathrm{Cu}$ removal process from electroplating wastewater. Furthermore, the $\mathrm{Cu}$ removal efficiency decreases significantly with the increase in the initial $\mathrm{Cu}$ concentration from 36.9 to $145.73 \mathrm{mg} / \mathrm{L}$. The decrease in $\mathrm{Cu}$ removal efficiency at high initial $\mathrm{Cu}$ concentration is due to the presence of a high amount of hydroxyl radical scavengers. When the initial $\mathrm{Cu}$ concentration is high, the photochemical oxidation process is overloaded. As a result, the $\mathrm{Cu}$ in the solution competes with each other during the oxidation reaction process [29]. On the other hand, in the UV irradiation process, the permeation of photons is reduced at high solution concentration; therefore, the concentration of hydroxyl radical produced is low [29]. Therefore, the oxidation of $\mathrm{Cu}$ decreases at high initial $\mathrm{Cu}$ concentration. This finding is in accordance with several previous studies in AOP. Hassan et al. [30] reported that the decolorization of Direct Yellow 50 dye in seawater through the UV-Ozone process was highly affected by the initial dye concentration, i.e., the decolorization rate decreased by increasing the dye concentration. Dai et al. [31] also reported a similar finding in the degradation of carbamazepine in water through AOP. They reported that the degradation percentage of carbamazepine decreased from $34 \%$ to $13 \%$ with an increase in the initial carbamazepine concentration from 4.2 to $42.3 \mu \mathrm{M}$. Jing et al. [32] also reported that the initial aniline concentration affected the aniline degradation process through ozonation. They reported that aniline degradation decreased with the increase in the initial aniline concentration due to the overload of the ozonation process.

\subsubsection{Effect of Ozone Dosage}

In this study, the effect of ozone dosage on the Cu removal process through the photochemical oxidation process is studied by varying the ozone dosage. The ozone dosage was varied at 5,10 , and $15 \mathrm{mg} / \mathrm{h}$. Cu removal efficiency was monitored to study this matter. The effect of ozone dosage on $\mathrm{Cu}$ removal efficiency is depicted in Figure 6.

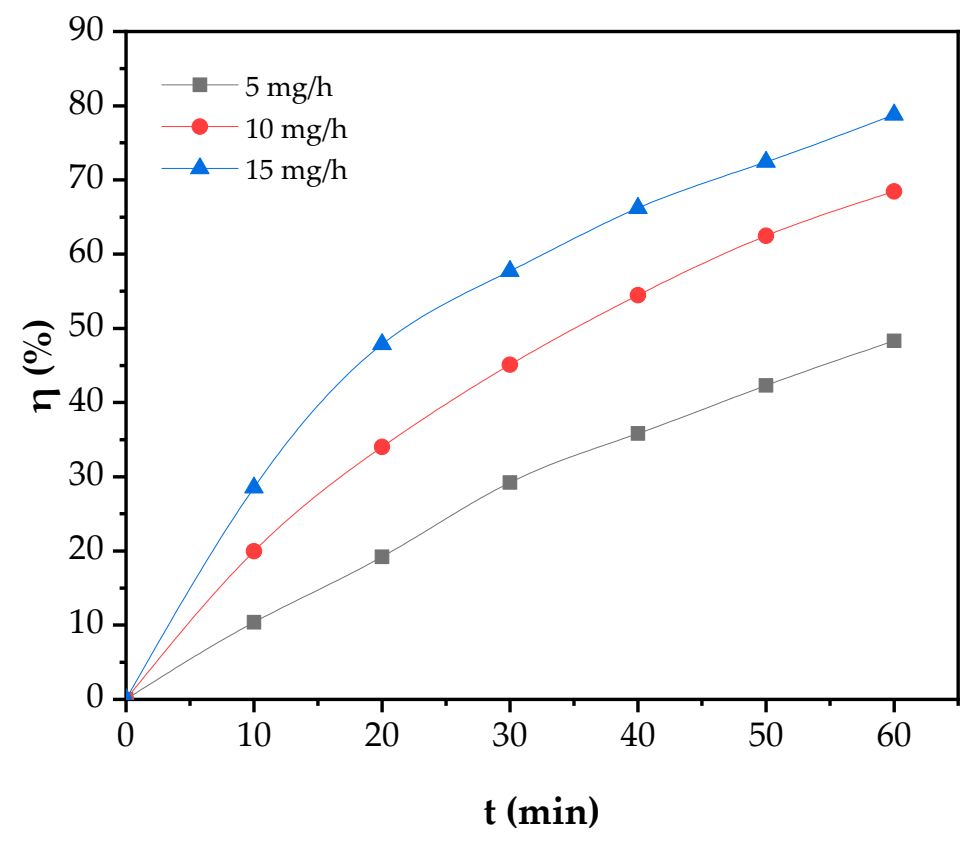

Figure 6. Effect of ozone dosage on $\mathrm{Cu}$ removal efficiency through a photochemical process. 
As can be seen in Figure 6, the $\mathrm{Cu}$ removal efficiency increases significantly with increasing the ozone dosage. At $60 \mathrm{~min}$ reaction, the $\mathrm{Cu}$ removal efficiency obtained at ozone dosage of $5 \mathrm{mg} / \mathrm{h}$ is $48.31 \%$, the Cu removal efficiency obtained at ozone dosage of $10 \mathrm{mg} / \mathrm{h}$ is $68.46 \%$, while the $\mathrm{Cu}$ removal efficiency obtained at ozone dosage of $15 \mathrm{mg} / \mathrm{h}$ is $78.80 \%$. Based on these results, it is suggested that the $\mathrm{Cu}$ removal efficiency in $\mathrm{Cu}$ removal from electroplating wastewater through the photochemical oxidation process is highly affected by the ozone dosage. As the ozone dosage increases, the $\mathrm{Cu}$ removal efficiency increases. It is true since in the ozonation process, the oxidation of $\mathrm{Cu}$ can occur through two different mechanisms, i.e., oxidation by HO• radicals (Equation (2)) and direct oxidation by ozone (Equation (3)). As reported by Wang et al. [33], in the ozone-based oxidation process, there are two methods, namely, indirect reaction of free radicals and direct reaction.

Pertaining to the effect of ozone dosage on $\mathrm{HO} \bullet$ radical formation, when ozone dosage increases, more $\mathrm{HO} \bullet$ radicals are formed. Under UV irradiation, $\mathrm{H}_{2} \mathrm{O}_{2}$ can be formed through the reaction of ozone with $\mathrm{H}_{2} \mathrm{O}$ (Equation (8)). Furthermore, this $\mathrm{H}_{2} \mathrm{O}_{2}$ molecule absorbs the $\mathrm{UV}$ light to generate the $\mathrm{HO} \bullet$ radicals (Equation (9)) [24]. Ozone molecules also can react with $\mathrm{H}_{2} \mathrm{O}_{2}$ molecules to produce $\mathrm{HO} \bullet$ radicals. Besides, the ozone also can also directly react with $\mathrm{H}_{2} \mathrm{O}$ to generate $\mathrm{HO} \bullet$ radicals (Equation (7)). Then, $\mathrm{Cu}$ is oxidized by $\mathrm{HO} \bullet$ radicals. Therefore, the photochemical oxidation rate of $\mathrm{Cu}$ increases with the increase in ozone dosage. As a comparison, Wang et al. [33] reported that the decomplexation of electroplating wastewater by the ozone-based oxidation process increased with the increase in ozone dosage. Ren et al. [24] reported that the removal efficiency of polyacrylamide through the photochemical oxidation process increased with the increase in ozone dosage. Guo et al. [34] also reported the same result in the degradation process of sulfadiazine in water by the UV-Ozone process.

\subsubsection{Effect of UV Irradiation Intensity}

In order to study the effect of UV irradiation intensity on $\mathrm{Cu}$ removal from electroplating wastewater, the photochemical process was conducted by varying the UV irradiation intensity. The UV irradiation intensity was varied at 20,40 , and $60 \mathrm{~mW} / \mathrm{cm}^{2}$. Figure 7 shows the result of the effect of UV irradiation intensity on $\mathrm{Cu}$ removal efficiency.

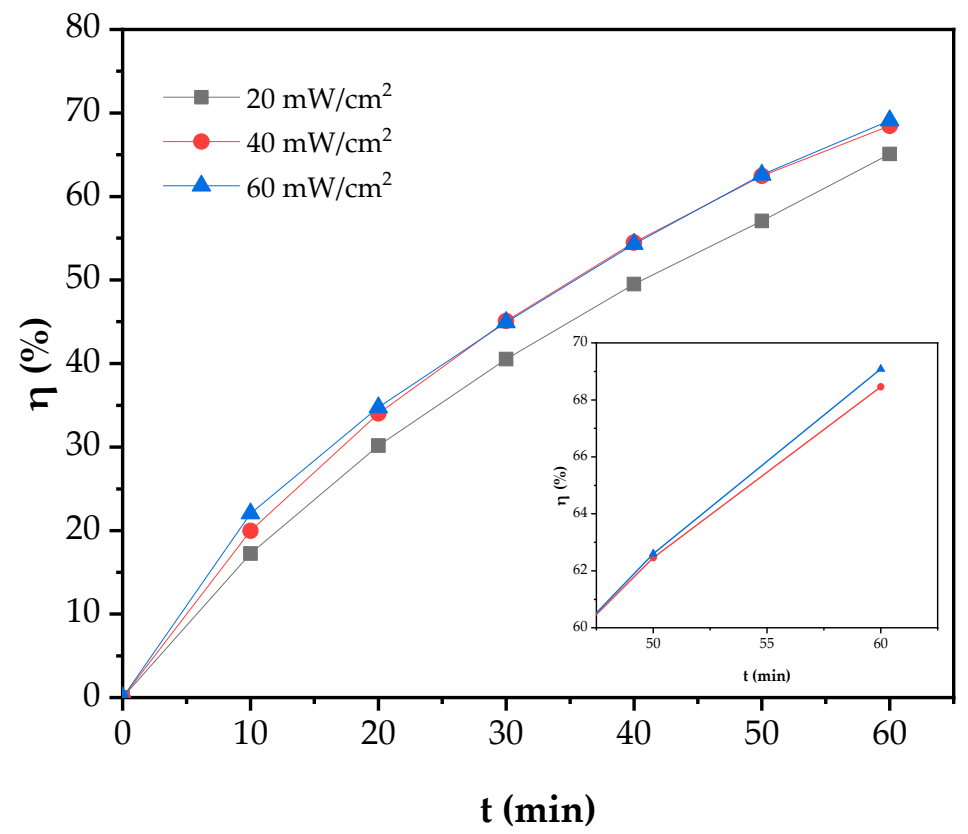

Figure 7. Effect of UV irradiation intensity on $\mathrm{Cu}$ removal efficiency through photochemical process.

As shown in Figure 7, at 60 min reaction, the $\mathrm{Cu}$ removal efficiency obtained at a UV irradiation intensity of $20 \mathrm{~mW} / \mathrm{cm}^{2}$ is $65.09 \%$, the Cu removal efficiency obtained at UV irradiation intensity 
of $40 \mathrm{~mW} / \mathrm{cm}^{2}$ is $68.46 \%$, while the Cu removal efficiency obtained at UV irradiation intensity of $60 \mathrm{~mW} / \mathrm{cm}^{2}$ is $69.08 \%$. It can be concluded that the $\mathrm{Cu}$ photochemical oxidation rate slightly increases with the increase in UV radiation intensity. The Cu removal efficiency slightly increases for UV irradiation of $20-40 \mathrm{~mW} / \mathrm{cm}^{2}$. Furthermore, the Cu removal efficiency remains unchanged for UV irradiation intensity of $40-60 \mathrm{~mW} / \mathrm{cm}^{2}$.

The increase in Cu removal efficiency with the increase in UV irradiation intensity is due to the high possibility to produce $\mathrm{HO} \bullet$ radicals at high UV irradiation intensity. The possible process of $\mathrm{HO} \bullet$ radical formation during UV irradiation is the photolytic dissociation of water by UV irradiation at a wavelength of $254 \mathrm{~nm}$ [35]. However, this process is still unclear since some studies reported that the photolytic dissociation of water to $\mathrm{HO} \bullet$ radicals only can be conducted at a wavelength of less than $242 \mathrm{~nm}$. Deng and Zhao [12] claimed that this process occurs at a wavelength of less than $242 \mathrm{~nm}$. Furthermore, Jin et al. [22] reported that the $\mathrm{HO} \bullet$ radicals could be formed through irradiation on liquid water by UV light in the range of $150-200 \mathrm{~nm}$. As the UV irradiation wavelength used in this study is around $253.7 \mathrm{~nm}$, the increase in Cu removal efficiency with the increase in UV irradiation intensity from 20 to $40 \mathrm{~mW} / \mathrm{cm}^{2}$ is attributed to the formation of HO• radicals through ozone photolysis producing $\mathrm{H}_{2} \mathrm{O}_{2}$ (Equation (8)). However, high UV irradiation intensity in the ozonation process is not good. It is true since, at high UV irradiation intensity, the ozone molecule could be degraded to oxygen [36]. Therefore, the formation of HO• radicals is low at high UV irradiation intensity. Furthermore, it is suggested that the unchanged $\mathrm{Cu}$ removal efficiency at a UV irradiation intensity of $60 \mathrm{~mW} / \mathrm{cm}^{2}$ is due to the degradation of the ozone molecule resulting in the low formation of $\mathrm{HO} \bullet$ radicals.

\subsubsection{Effect of $\mathrm{pH}$}

The efficiency of AOP can be influenced by various factors, such as the $\mathrm{pH}$ of the solution [37-39]. In order to study the effect of $\mathrm{pH}$ on the $\mathrm{Cu}$ removal process from electroplating wastewater through the photochemical oxidation process, the $\mathrm{pH}$ of solution was varied at $3,6,8$, and 10 . The result is depicted in Figure 8.

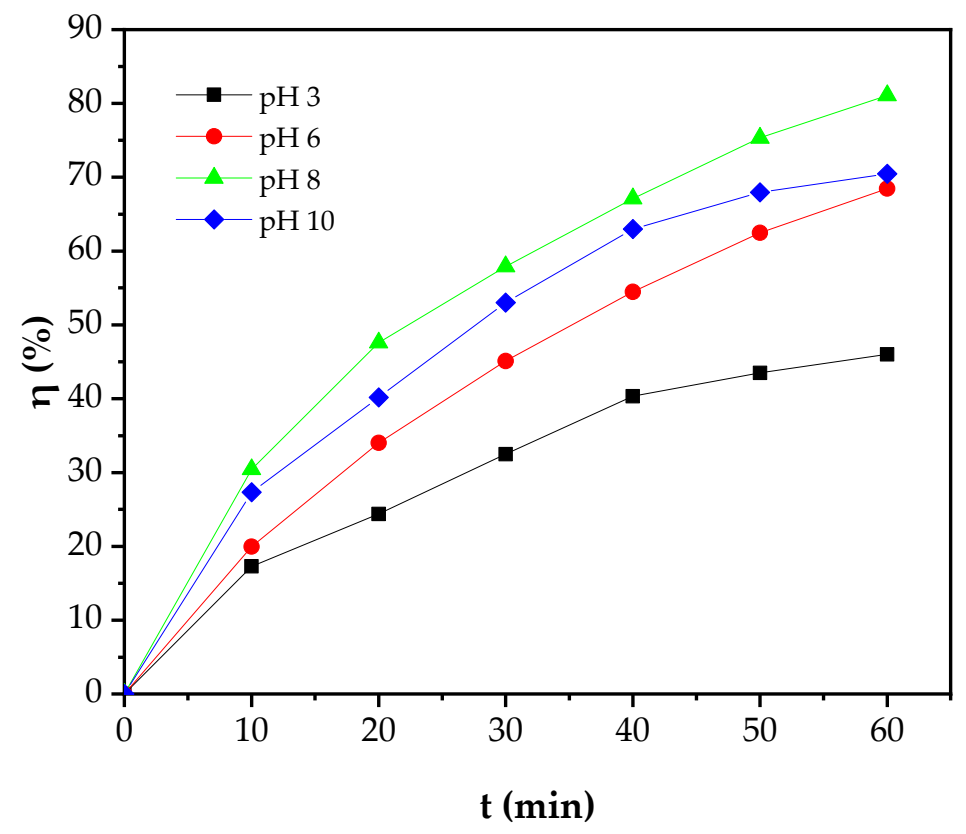

Figure 8. Effect of $\mathrm{pH}$ on $\mathrm{Cu}$ removal efficiency through photochemical process.

As can be seen in Figure 8, at 60 min reaction, the Cu removal efficiency obtained at $\mathrm{pH}$ of 3 is $46.02 \%$, the $\mathrm{Cu}$ removal efficiency obtained at $\mathrm{pH}$ of 6 is $68.46 \%$, the $\mathrm{Cu}$ removal efficiency obtained at $\mathrm{pH}$ of 8 is $80.09 \%$, while the Cu removal efficiency obtained at $\mathrm{pH}$ of 10 is $70.46 \%$. It can be seen 
that the highest $\mathrm{Cu}$ removal efficiency is obtained at a $\mathrm{pH}$ of 8 . Hence, it can be concluded that the photochemical oxidation of $\mathrm{Cu}$ from electroplating wastewater increases with the increase in $\mathrm{pH}$ from 3 to 8 , then it decreases with a further increase in $\mathrm{pH}$ to 10 .

The increase in $\mathrm{Cu}$ removal efficiency with the increase in $\mathrm{pH}$ value is attributed to the high rate of $\mathrm{HO} \bullet$ radical formation at high $\mathrm{pH}$ conditions. As reported by Muniyasamy et al. [39], in the oxidation process, $\mathrm{pH}$ influences the process by altering the chemical nature of ozone. At low $\mathrm{pH}$ conditions (acidic conditions), the decomposition of the ozone molecule to produce HO• radicals is relatively slow [40]. It was reported that the decomposition rate of ozone was sluggish below the $\mathrm{pH}$ of 4 [41]. Furthermore, ozone tends to remain in the molecular state at acidic conditions; however, ozone can react directly as ozone radical with the contaminants at alkaline conditions [38,42]. Therefore, the $\mathrm{Cu}$ removal efficiency is low at a low $\mathrm{pH}$ value. Furthermore, the higher the $\mathrm{pH}$ value, the higher the $\mathrm{Cu}$ removal efficiency. This tendency is attributed to the high formation of HO• radicals at the alkaline conditions. It was reported that the decomposition rate of ozone in water is better at higher $\mathrm{pH}$ values [43]. At alkaline conditions, ozone is unstable and rapidly decomposes into HO• radical $[39,40]$. The $\mathrm{HO} \bullet$ radical formation through ozone decomposition occurs as follows:

$$
\begin{gathered}
\mathrm{O}_{3}+\mathrm{OH}^{-} \rightarrow \mathrm{HO}_{2}^{-}+\mathrm{O}_{2} \\
2 \mathrm{O}_{3}+\mathrm{HO}_{2}^{-} \rightarrow \mathrm{HO} \bullet+\mathrm{O}_{2}^{-} \bullet+\mathrm{O}_{2} .
\end{gathered}
$$

As can be seen in Equations (16) and (17), the HO• radical, which is the primary oxidant in indirect oxidation [39], is produced at high $\mathrm{pH}$ level represented as $\mathrm{OH}^{-}$. Therefore, the $\mathrm{Cu}$ removal efficiency increases with the increase in $\mathrm{pH}$ value since the $\mathrm{HO} \bullet$ radical formation is favored at a high $\mathrm{pH}$ level. However, the $\mathrm{Cu}$ removal efficiency decrease at a $\mathrm{pH}$ of 10 . At higher $\mathrm{pH}$ value, $\mathrm{CuO}$ can dissolve to the aqueous phase due to the formation of soluble hydroxy and hydroxide complexes [44]. Therefore, $\mathrm{Cu}$ removal efficiency decreases. The possible dissolution mechanism of $\mathrm{CuO}$ at high $\mathrm{pH}$ value was proposed by Khan et al. [44] as follows:

$$
\begin{gathered}
\mathrm{CuO}_{(s)}+\mathrm{OH}_{(a q)}^{-}+\mathrm{H}_{2} \mathrm{O}_{(l)} \rightleftharpoons \mathrm{Cu}(\mathrm{OH})_{3(a q)}^{-} \\
\mathrm{CuO}_{(s)}+2 \mathrm{OH}_{(a q)}^{-}+\mathrm{H}_{2} \mathrm{O}_{(l)} \rightleftharpoons \mathrm{Cu}(\mathrm{OH})_{4}^{2-}{ }_{(a q)} .
\end{gathered}
$$

\subsection{Kinetic Study}

\subsubsection{Determination of the Kinetic Rate Order}

Three classical kinetic models are proposed to describe the $\mathrm{Cu}$ removal process and to determine the order or kinetic rate. These kinetic models include first-order model, second-order model, and pseudo-first-order model. The compatibility of these models is evaluated by the $\mathrm{R}^{2}$ value as reported elsewhere [45]. In this work, the kinetic study of $\mathrm{Cu}$ removal from electroplating wastewater is considered for various initial $\mathrm{Cu}$ concentration $\left(C_{0}\right)$, ozone dosage $\left(C_{O 3}\right), \mathrm{UV}$ irradiation intensity $\left(I_{U V}\right)$, and initial $\mathrm{pH}$ condition.

In this advanced oxidation process for $\mathrm{Cu}$ removal from electroplating wastewater, the mass conservation of $\mathrm{Cu}$ in the process can be generally expressed as:

$$
-\frac{d C_{t}}{d t}=(-r)
$$

where $C_{t}(\mathrm{mg} / \mathrm{L})$ is the concentration of $\mathrm{Cu}$ at time $t(\mathrm{~min})$ and $(-r)(\mathrm{mg} / \mathrm{L} \cdot \mathrm{min})$ is the rate of $\mathrm{Cu}$ removal. For first order model $\left(-r=k_{1} C_{t}\right)$, integration of Equation (20) at the initial concentration of $C_{0}$, gives:

$$
-\ln \left(\frac{C_{t}}{C_{0}}\right)=k_{1} t
$$


where $k_{1}(1 / \mathrm{min})$ is the kinetic rate constant for first order. Further simplification of Equation (21) will give the time-dependent concentration of $\mathrm{Cu}$ (Equation (22)).

$$
C_{t}=C_{0} e^{-k_{1} t}
$$

For second-order model $\left(-r=k_{2} C_{t}^{2}\right)$, the integration of Equation (20) will give:

$$
\frac{1}{C_{t}}=k_{2} t+\frac{1}{C_{0}}
$$

where $k_{2}(\mathrm{~L} / \mathrm{mg} \cdot \mathrm{min})$ is the kinetic rate constant of the second-order model. For the pseudo-first-order model $\left(-r=k_{p}\left(C_{t}-C_{e}\right)\right)$, the time-dependent concentration of $\mathrm{Cu}$ through the integration of Equation (20) is obtained as:

$$
C_{t}=C_{e}+\left(C_{0}-C_{e}\right) e^{-k_{p} t},
$$

where $C_{e}(\mathrm{mg} / \mathrm{L})$ is the concentration of $\mathrm{Cu}$ at equilibrium condition and $k_{p}(1 / \mathrm{min})$ is the kinetic rate constant of pseudo-first-order model.

The kinetic parameters were determined using the least-square method. As can be seen, the obtained equation for first-order and second-order kinetic models (Equations (21) and (23)) are linear equations. Therefore, the kinetic parameters $\left(k_{1}\right.$ and $\left.k_{2}\right)$ can be obtained from the linear plot relating to these equations using the linear regression method. However, the equation derived from the pseudo-first-order kinetic model is not linear. Therefore, the kinetic parameters of the pseudo-first-order kinetic model $\left(C_{e}\right.$ and $\left.k_{p}\right)$ are calculated using a nonlinear regression method. On the other hand, to measure the goodness of the kinetic models proposed, the squared-correlation coefficient, $R^{2}$, was used as the parameter $[40,41]$. The obtained kinetic parameters and $R^{2}$ values for first-order,

\begin{tabular}{|c|c|c|c|c|c|c|c|c|c|c|}
\hline \multirow{3}{*}{$\begin{array}{c}C_{0} \\
(\mathrm{mg} / \mathrm{L})\end{array}$} & \multirow{3}{*}{$\begin{array}{c}C_{\mathrm{O} 3} \\
(\mathrm{mg} / \mathrm{h})\end{array}$} & \multirow{3}{*}{$\begin{array}{c}I_{U V} \\
\left(\mathrm{~mW} / \mathrm{cm}^{2}\right)\end{array}$} & \multirow{3}{*}{$\mathrm{pH}$} & \multicolumn{7}{|c|}{ Kinetic Parameters } \\
\hline & & & & \multicolumn{2}{|c|}{ First-Order } & \multicolumn{2}{|c|}{ Second-Order } & \multicolumn{3}{|c|}{ Pseudo-First-Order } \\
\hline & & & & $\begin{array}{c}k_{1} \\
(1 / \mathrm{min})\end{array}$ & $\mathbf{R}^{2}$ & $\begin{array}{c}k_{2} \\
(\mathrm{~L} / \mathrm{mg} \cdot \mathrm{min})\end{array}$ & $\mathbf{R}^{2}$ & $\begin{array}{c}k_{p} \\
(1 / \mathrm{min})\end{array}$ & $\begin{array}{c}C_{e} \\
(\mathrm{mg} / \mathrm{L})\end{array}$ & $\mathbf{R}^{2}$ \\
\hline 145.73 & 10 & 40 & 6 & 0.0069 & 0.9997 & $5.673 \times 10^{-5}$ & 0.9921 & 0.0069 & 0.000 & 0.9994 \\
\hline 72.86 & 10 & 40 & 6 & 0.0128 & 0.9993 & $2.451 \times 10^{-4}$ & 0.9678 & 0.0127 & 0.000 & 0.9983 \\
\hline 36.9 & 10 & 40 & 6 & 0.0196 & 0.9995 & $8.898 \times 10^{-4}$ & 0.9707 & 0.0237 & 3.769 & 0.9995 \\
\hline 36.9 & 5 & 40 & 6 & 0.0111 & 0.9998 & $3.972 \times 10^{-4}$ & 0.9875 & 0.0116 & 1.223 & 0.9993 \\
\hline 36.9 & 15 & 40 & 6 & 0.0267 & 0.9959 & $1.480 \times 10^{-3}$ & 0.9624 & 0.0395 & 5.528 & 0.9979 \\
\hline 36.9 & 10 & 20 & 6 & 0.0173 & 0.9996 & $7.407 \times 10^{-4}$ & 0.9609 & 0.0188 & 1.850 & 0.9990 \\
\hline 36.9 & 10 & 60 & 6 & 0.0198 & 0.9989 & $9.031 \times 10^{-4}$ & 0.9654 & 0.0252 & 4.663 & 0.9969 \\
\hline 36.9 & 10 & 40 & 3 & 0.0116 & 0.9847 & $4.160 \times 10^{-4}$ & 0.9790 & 0.0330 & 12.126 & 0.9940 \\
\hline 36.9 & 10 & 40 & 8 & 0.0282 & 0.9980 & $1.650 \times 10^{-3}$ & 0.9359 & 0.0376 & 4.170 & 0.9962 \\
\hline 36.9 & 10 & 40 & 10 & 0.0226 & 0.9904 & $1.100 \times 10^{-3}$ & 0.9909 & 0.0381 & 7.725 & 0.9970 \\
\hline
\end{tabular}
second-order, and pseudo-first-order kinetic models are shown in Table 1.

Table 1. Kinetic parameters of the first order, second-order, and pseudo-first-order models.

As can be seen in Table 1, all proposed models fit the data as the $\mathrm{R}^{2}$ values are close to unity. However, compared to the other proposed models, the $R^{2}$ value of the second-order model is far enough from unity. Besides, the values of $\mathrm{R}^{2}$ obtained are not uniform for all data. Therefore, it is suggested that the second-order model is excluded as the proposed model to describe the kinetic rate of $\mathrm{Cu}$ removal. Hence, the first order and pseudo-first-order models are then considered as the most suitable proposed models to describe the kinetics of $\mathrm{Cu}$ removal. Considering the $\mathrm{R}^{2}$ values of the first order and pseudo-first-order models, both these two models have high goodness in describing the kinetic rate of $\mathrm{Cu}$ removal. However, at the initial $\mathrm{Cu}$ concentration, $\mathrm{C}_{0}$, of 145.73 and $72.86 \mathrm{mg} / \mathrm{L}$, the value of the equilibrium concentrations, $C_{e}$, obtained are zero. It indicates that at a high initial concentration of $\mathrm{Cu}$ in the wastewater, the kinetic rate will be increased. Furthermore, some of the $C_{e}$ values are relatively low. In some cases, the theoretical value of $C_{e}$ might be negative when the pseudo-first-order 
kinetic model is forcibly used [46]. In those cases, the pseudo-first-order model cannot be used to describe the kinetic rate. Obviously, if the value of the equilibrium concentration is zero or low enough, the pseudo-first-order model gets back to the first-order model $[45,46]$. Therefore, it is suggested that the most suitable model to describe the kinetic rate of $\mathrm{Cu}$ removal from electroplating wastewater through the photochemical oxidation process, combined UV-Ozone process, is the first-order model.

The kinetic study of $\mathrm{Cu}$ removal using an advanced oxidation process has been widely reported. However, the kinetic study of $\mathrm{Cu}$ removal using the photochemical oxidation process, UV-Ozone process, is still limited. The most-reported process is the electrochemical/electrocoagulation process. Al-Shannag et al. [45] reported that the electrocoagulation of heavy metals from wastewater, including $\mathrm{Cu}$, followed a pseudo-first-order model. Using the same method, Vasudevan and Lakshmi [47] reported that the electrocoagulation of $\mathrm{Cu}$ from water follows the second-order model. Furthermore, Khattab et al. [48] reported that $\mathrm{Cu}$ removal through the electrochemical process follows the first-order kinetic model.

\subsubsection{The Effect of Operating Parameters on Kinetic Rate Constant}

The kinetic rate behavior of $\mathrm{Cu}$ removal using the photochemical oxidation process, combined UV-Ozone process, follows the first-order kinetic model as reported in Section 3.3.1. The value of the kinetic rate constant of the first-order model, $k_{1}$, is presented in Table 1 . As can be observed, the value of $k_{1}$ is varied as the variation of operating parameters, including $C_{0}, C_{O 3}, I_{U V}$, and $\mathrm{pH}$. The value of $k_{1}$ increases with a decrease in $C_{0}$. Furthermore, the value of $k_{1}$ increases with the increase in $C_{O 3}, I_{U V}$, and $\mathrm{pH}$. However, at a $\mathrm{pH}$ of 10 , the value of $k_{1}$ decreases. These phenomena indicate that the value of the observed $k_{1}$ is affected by the operating parameters. This is in accordance with some previous studies that the kinetic rate constant of the advanced oxidation process, especially the UV-Ozone process, is affected by the operating parameters [24,49]. The operating parameters-dependent of the kinetic rate constant can be mathematically written as Equations (25) and (26) where $\varepsilon$ is the pre-exponent constant, whereas $a, b, c$, and $d$ are the exponent constant characteristic of $C_{0}, C_{O 3}, I_{U V}$, and $\mathrm{pH}$, respectively. The linear form of Equation (26) is shown as Equation (27).

$$
\begin{gathered}
k_{1}=f\left(C_{0}, C_{O_{3}}, I_{U V}, p H\right) \\
k_{1}=\varepsilon C_{0}^{a} C_{O_{3}}^{b} I_{U V}^{c} p H^{d} \\
\ln k_{1}=\ln \varepsilon+a \ln C_{0}+b \ln C_{O_{3}}+c \ln I_{U V}+d \ln p H .
\end{gathered}
$$

Based on Equation (27), the value of $\varepsilon, a, b, c$, and $d$ can be obtained using multiple regression analysis which also has been used elsewhere [49]. However, the value of $k_{1}$ at a $\mathrm{pH}$ of 10 is not included in this calculation because it does not follow the tendency. Table 2 shows the result of the multiple regression analysis. As can be seen, the $p$-value of the coefficients obtained for each parameter is lower than 0.05 . This indicates that the coefficients obtained are significant. However, the $p$-value of $\ln I_{U V}$ coefficient is higher than 0.05 , which indicates that this coefficient is not significant. Table 3 shows the result of the analysis of variance (ANOVA) of the multiple regression analysis. As can be observed, the value of multiple $R, R^{2}$, and adjusted $R^{2}$ is close to unity. These indicate that the obtained regression equation fits the data. Furthermore, the obtained $F$-value (113.4928) is higher than the $F$-table or theoretical $F$-value. The theoretical $F$-value $\left(\mathrm{F}_{0.05(4,7)}\right)$ is 6.09 .

Based on the result of the multiple regression analysis (Table 2), Equation (27) can be rewritten as Equation (28). Furthermore, Equation (26) can be rewritten as Equation (29) with the value of $\varepsilon$ constant calculated from the natural exponential of the intercept of Equation (28). The obtained value of $k_{1}$ was then compared to the calculated value of $k_{1}$ using Equation (29). The comparison of the observed $k_{1}$ and calculated $k_{1}$ is depicted in Figure 9. It is clear that the observed and calculated values of $k_{1}$ are in good fit as the $R^{2}$ is close to unity (0.9848). By combining the Equations (1), (22) and (29), the calculated $\mathrm{Cu}$ removal efficiency can be rewritten as Equation (30). Furthermore, the comparison 
of the $\mathrm{Cu}$ removal efficiency between the observed value and the calculated value is also depicted in Figure 10.

$$
\begin{gathered}
\ln k_{1}=-5.1661-0.7401 \ln C_{0}+0.8154 \ln C_{O_{3}}+0.1441 \ln I_{U V}+0.8407 \ln p H \\
k_{1}=\left(5.7068 \times 10^{-3}\right) C_{0}^{-0.7401} C_{O_{3}}^{0.8154} I_{U V}^{0.1441} p H^{0.8407} \\
\eta_{c a l}(\%)=100-100 \exp \left(-\left(5.7068 \times 10^{-3}\right) C_{0}^{-0.7401} C_{O_{3}}^{0.8154} I_{U V}^{0.1441} p H^{0.8407} t\right)
\end{gathered}
$$

Table 2. Multiple regression analysis result.

\begin{tabular}{cccc}
\hline Parameters & Coefficients & Standard Error & $p$-value \\
\hline Intercept & -5.1661 & 0.3951 & $3.5663 \times 10^{-6}$ \\
$\ln C_{0}$ & -0.7401 & 0.0441 & $6.4919 \times 10^{-7}$ \\
$\ln C_{O 3}$ & 0.8154 & 0.0778 & $1.5626 \times 10^{-5}$ \\
$\ln I_{U V}$ & 0.1441 & 0.0778 & 0.1064 \\
$\ln \mathrm{pH}$ & 0.8407 & 0.0839 & $2.1105 \times 10^{-5}$ \\
\hline
\end{tabular}

Table 3. Summary of the analysis of variance (ANOVA).

\begin{tabular}{cccccc}
\hline & $d f$ & SS & MS & $\boldsymbol{F}$ & Significance $\boldsymbol{F}$ \\
\hline Regression & 4 & 1.7467 & 0.4367 & 113.4928 & $1.9188 \times 10^{-6}$ \\
Residual & 7 & 0.0269 & 0.0038 & & \\
Total & 11 & 1.7736 & & & \\
Multiple R & 0.9924 & & & & \\
$\mathrm{R}^{2}$ & 0.9848 & & & & \\
Adjusted R & 0.9761 & & & & \\
Standard error & 0.0620 & & & & \\
\hline
\end{tabular}

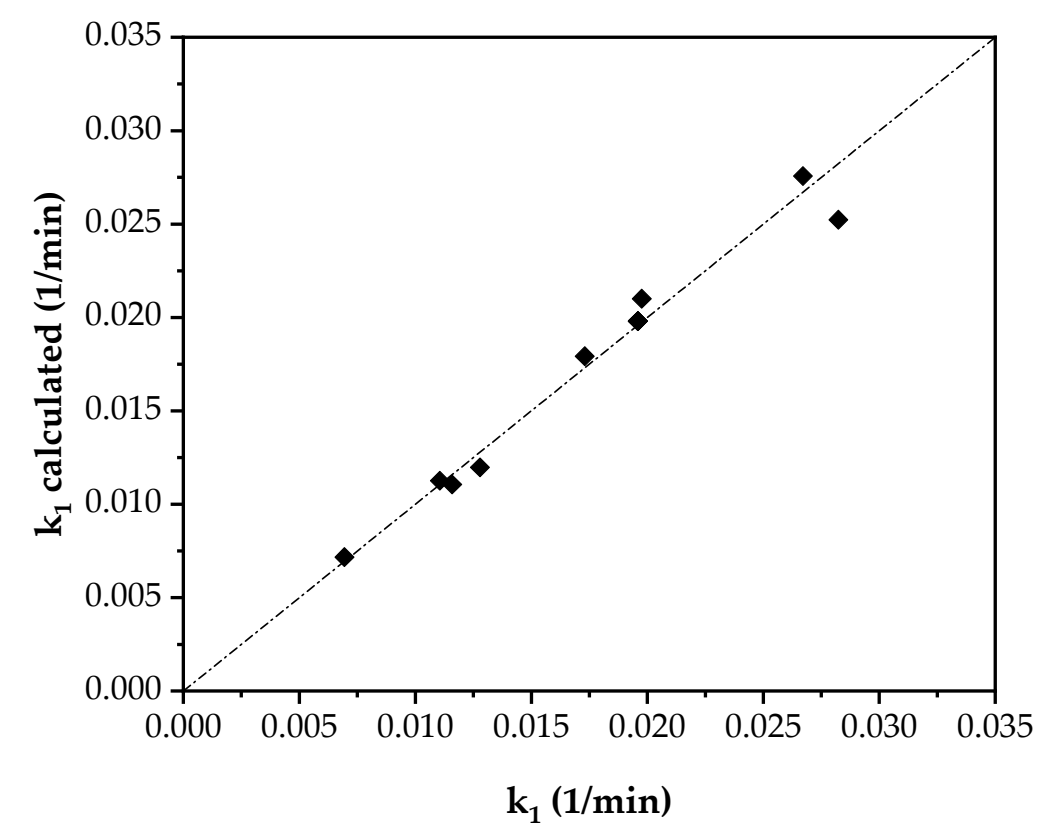

Figure 9. Comparison of observed and calculated value of $k_{1}$. 


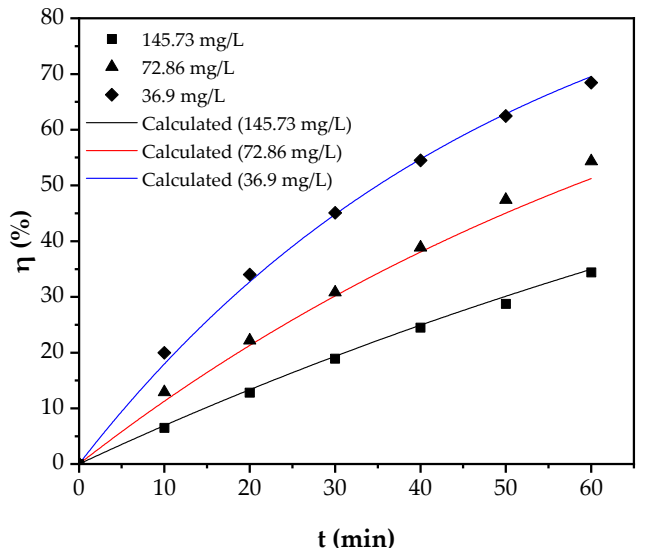

(a)

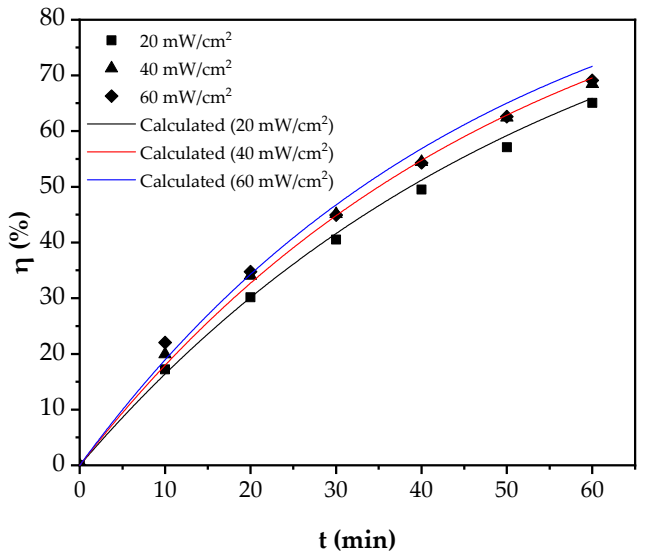

(c)

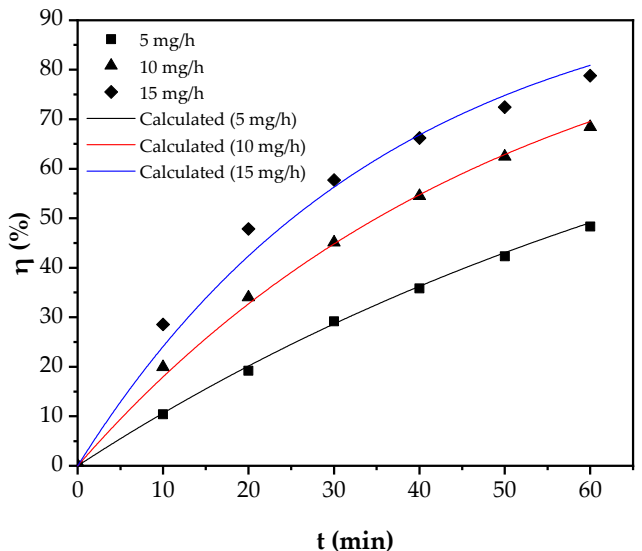

(b)

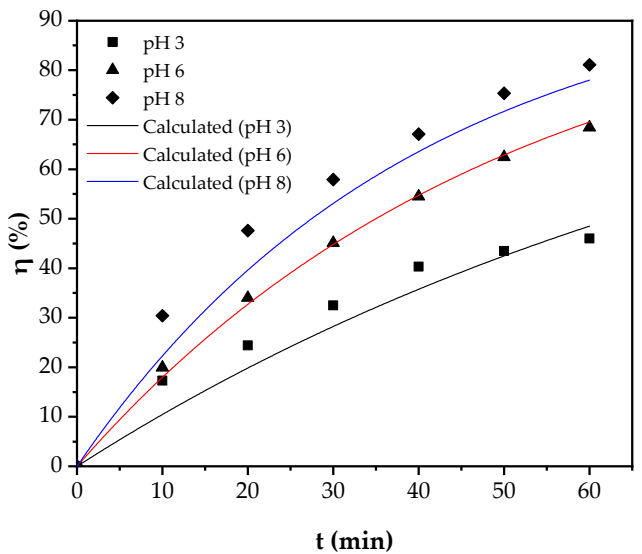

(d)

Figure 10. Comparison of data and calculated $\mathrm{Cu}$ removal efficiency at $(\mathbf{a})$ varied $C_{0},(\mathbf{b})$ varied $C_{O 3}$, (c) varied $I_{U V}$, and (d) varied $\mathrm{pH}$.

As can be seen in Table 2 and Equation (29), the exponent characteristic value of $C_{0}$ is in a negative value. It indicates that the value of the initial $\mathrm{Cu}$ concentration is inversely proportional to the $k_{1}$ value. This finding is in accordance with the finding of Ren et al. [24]. They reported that the initial concentration of polyacrylamide in the UV-Ozone process of polyacrylamide oxidation is inversely proportional to the kinetic rate constant value. Concerning the effect of UV and ozone treatment in this oxidation process, the value of the exponent characteristic of $C_{O 3}$ and $I_{U V}$ can be used to study this matter [49]. As can be seen, the exponent characteristic value of $C_{O 3}$ is higher than $I_{U V}$. It is suggested that the ozone dosage is more significant in this oxidation process than UV irradiation intensity. This finding is in accordance with the previous study of the UV-Ozone process. The UV-Ozone process was conducted for $\mathrm{k}$-Carrageenan treatment, and the result showed that the ozone dosage was more significant than UV irradiation intensity [49]. Furthermore, the value of the exponent characteristic of $I_{U V}$ is low enough, and it is close to zero. It indicates that the UV irradiation intensity is not significant enough for the $\mathrm{Cu}$ removal process from wastewater. In the case of the effect of $\mathrm{pH}$ on $k_{1}$ value, it is clear that the $\mathrm{pH}$ has a significant effect on $k_{1}$ value as the value of the exponent characteristic of $\mathrm{pH}$ is high. It is true because the metal oxidation process in an aqueous solution is affected by the presence of $\mathrm{OH}^{-}$ions, which can promote the formation of $\mathrm{HO} \bullet$ radicals. On the other hand, the solubility of metal in aqueous solution is also affected by the $\mathrm{pH}$ value [44].

\subsection{Proposed Mechanism}

Based on the explanation in previous sections, the mechanism of $\mathrm{Cu}$ removal from electroplating wastewater through the UV-Ozone process is developed. Figure 11 shows the proposed mechanism in 
this study. As reported in several studies, the oxidation through AOPs is initiated by the formation of $\mathrm{HO} \bullet$ radical because the main oxidating agent is $\mathrm{HO} \bullet$ radical $[50,51]$. Based on several findings obtained in this study (reported in the previous sections), the HO• radical formation takes place through three different steps. In Figure 11, these steps are represented in orange, blue, and red arrows. The orange arrows represent the HO• radical formation through the UV-Ozone process. The blue arrow represents the direct ozonation of water producing $\mathrm{HO} \bullet$ radicals releasing $\mathrm{O}_{2}$ molecules. Furthermore, the red arrows represent the ozone degradation producing $\mathrm{HO} \bullet$ radicals in alkaline condition releasing $\mathrm{O}_{2}$ molecules. The red arrow is depicted in dash-line arrow type, this indicates that this process occurs in alkaline condition only due to the presence of $\mathrm{OH}^{-}$ions. At acidic condition, this process does not occur as $\mathrm{OH}^{-}$ions are not present.

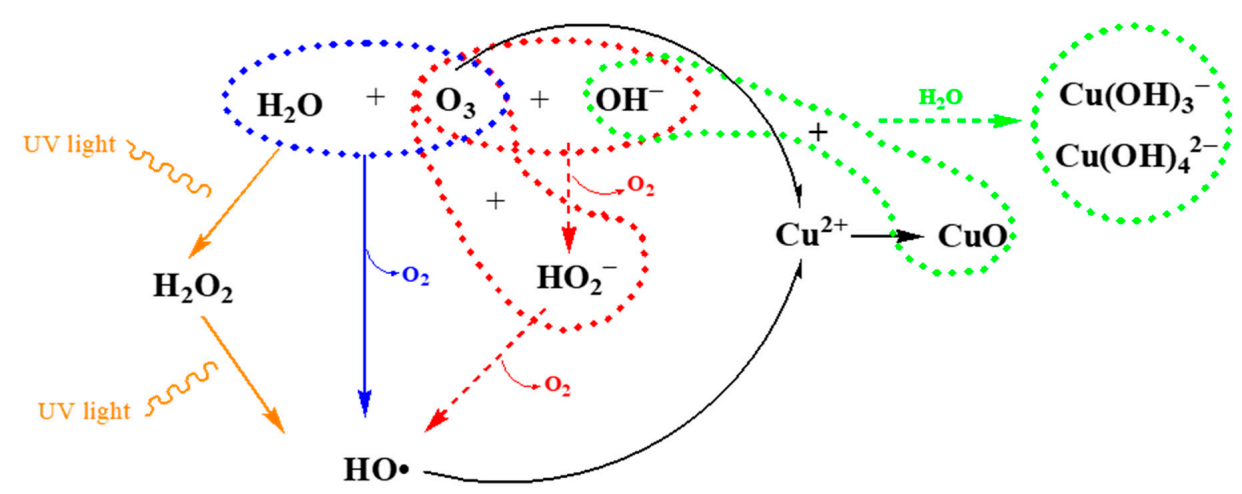

Figure 11. Proposed mechanism of $\mathrm{Cu}$ removal from electroplating wastewater through UV-Ozone process.

After the formation of $\mathrm{HO} \bullet$ radicals occurred, the next step is the oxidation process. This process, depicted in black arrows, includes direct and indirect oxidation since the oxidating agents in this UV-Ozone process are $\mathrm{HO} \bullet$ radicals and ozone molecules. Both $\mathrm{HO} \bullet$ radicals and $\mathrm{O}_{3}$ react with $\mathrm{Cu}^{2+}$ to form solid $\mathrm{CuO}$. The oxidation process of $\mathrm{Cu}^{2+}$ to $\mathrm{CuO}$ by $\mathrm{HO} \bullet$ radicals is called indirect oxidation, whereas the oxidation process of $\mathrm{Cu}^{2+}$ by $\mathrm{O}_{3}$ molecules is called direct oxidation. Based on Figure 11, as the $\mathrm{HO} \bullet$ radicals and $\mathrm{O}_{3}$ molecules increase in the system, the $\mathrm{CuO}$ product produced increases. It means that the $\mathrm{Cu}$ removal from the electroplating wastewater increases. However, this $\mathrm{CuO}$ product can dissolve in an alkaline condition. As can be seen in Figure 11, if the $\mathrm{OH}^{-}$ions are excessively present in the system, the $\mathrm{CuO}$ product will dissolve. This process is depicted as a dash-arrow in green indicating that this process occurs in alkaline condition only due to the presence of excessive $\mathrm{OH}^{-}$ ions. The dissolution of $\mathrm{CuO}$ to the aqueous phase in the alkaline condition is due to the formation of soluble hydroxy and hydroxide complexes [44].

Based on this proposed mechanism (Figure 11), it can be observed that the presence of the ozone molecule is important in this oxidation process. The ozone molecules have roles both to generate the $\mathrm{HO} \bullet$ radicals and to oxidize the $\mathrm{Cu}$ directly. This is in accordance with the finding reported in Section 3.4 that the ozone dosage significantly affected the kinetic rate. On the other hand, the presence of UV irradiation assists the ozone photolysis process to produce $\mathrm{HO} \bullet$ radicals through the formation of an intermediate oxidating agent, $\mathrm{H}_{2} \mathrm{O}_{2}$. Furthermore, the $\mathrm{pH}$ is also important in this mechanism. As can be seen in Figure 11, suitable alkaline condition accelerates the formation of HO• radicals. However, the high alkaline condition has a negative effect on the $\mathrm{Cu}$ removal process due to the $\mathrm{CuO}$ dissolution process in high alkaline condition. The excessive $\mathrm{OH}^{-}$ions catch the solid $\mathrm{CuO}$ to form soluble hydroxy and hydroxide complexes decreasing the $\mathrm{Cu}$ removal efficiency.

\section{Conclusions}

The photochemical oxidation process of $\mathrm{Cu}$ from electroplating wastewater has been investigated. It is shown that the UV-Ozone process has high performance on Cu removal compared to UV and Ozone 
processes due to the high production rate of $\mathrm{HO} \bullet$ radicals as the oxidant and due to the direct oxidation by ozone. Furthermore, this process produced a $\mathrm{CuO}$ monoclinic crystal phase as a solid product. The initial $\mathrm{Cu}$ concentration, ozone dosage, and $\mathrm{pH}$ value have a significant effect on $\mathrm{Cu}$ removal efficiency. The initial $\mathrm{Cu}$ concentration significantly reduces $\mathrm{Cu}$ removal efficiency. As expected, the ozone dosage increases the $\mathrm{Cu}$ removal efficiency since it is responsible for $\mathrm{HO} \bullet$ radical formation and direct oxidation. Furthermore, the $\mathrm{Cu}$ removal efficiency increases with the increase in $\mathrm{pH}$ value from 3 to 8 . However, a further increase in $\mathrm{pH}$ value reduces the $\mathrm{Cu}$ removal efficiency due to the formation of soluble hydroxy and hydroxide complexes of $\mathrm{Cu}$ at the alkaline conditions. Interestingly, it is found that the UV irradiation intensity is not significant in the photochemical oxidation process on $\mathrm{Cu}$ from electroplating wastewater. However, it is responsible to promote the ozone photolysis producing $\mathrm{HO} \bullet$ radicals through $\mathrm{H}_{2} \mathrm{O}_{2}$ formation. It is found that the kinetic behavior of the photochemical oxidation of $\mathrm{Cu}$ follows the first-order kinetic model. Furthermore, the relation between the operating parameters and kinetic rate constant is also established. In addition, the mechanism of $\mathrm{Cu}$ removal through the UV-Ozone process was also proposed concerning the findings obtained in this study.

Author Contributions: Conceptualization, A.P., M.D. and T.R.; methodology, A.P.; software, T.R.; validation, A.P., T.R., M.D. and W.W.; formal analysis, A.P.; investigation, A.P. and M.D.; resources, T.R.; data curation, W.W.; writing—original draft preparation, A.P. and T.R.; writing—review and editing, W.W.; visualization, A.P.; supervision, A.P.; project administration, A.P. All authors have read and agreed to the published version of the manuscript.

Funding: This research and the APC were funded by the Ministry of Education and Culture, Indonesia, through the research project of Penelitian Terapan Unggulan Perguruan Tinggi (PTUPT) with contract number: 225-138/UN7.6.1/PP/2020.

Acknowledgments: The authors would like to acknowledge the Ministry of Education and Culture, Indonesia, for the financial support.

Conflicts of Interest: The authors declare no conflict of interest. In addition, the funders had no role in the design of the study; in the collection, analyses, or interpretation of data; in the writing of the manuscript; or in the decision to publish the results.

\section{References}

1. Rahman, M.S.; Sathasivam, K.V. Heavy Metal Adsorption onto Kappaphycus sp. from Aqueous Solutions: The Use of Error Functions for Validation of Isotherm and Kinetics Models. Biomed Res. Int. 2015, 2015, 126298. [CrossRef] [PubMed]

2. Ali, M.M.; Ali, M.L.; Islam, M.S.; Rahman, M.Z. Preliminary assessment of heavy metals in water and sediment of Karnaphuli River, Bangladesh. Environ. Nanotechnol. Monit. Manag. 2016, 5, 27-35. [CrossRef]

3. Islam, M.S.; Ahmed, M.K.; Habibullah-Al-Mamun, M.; Islam, K.N.; Ibrahim, M.; Masunaga, S. Arsenic and lead in foods: A potential threat to human health in Bangladesh. Food Addit. Contam. Part A 2014, 31, 1982-1992. [CrossRef] [PubMed]

4. Khan, S.; Cao, Q.; Zheng, Y.M.; Huang, Y.Z.; Zhu, Y.G. Health risks of heavy metals in contaminated soils and food crops irrigated with wastewater in Beijing, China. Environ. Pollut. 2008, 152, 686-692. [CrossRef] [PubMed]

5. Gautam, R.K.; Sharma, S.K.; Mahiya, S.; Chattopadhyaya, M.C. Contamination of Heavy Metals in Aquatic Media: Transport, Toxicity and Technologies for Remediation. In Heavy Metals in Water; Royal Society of Chemistry: Cambridge, UK, 2014; pp. 1-24.

6. Majumder, S.; Gangadhar, G.; Raghuvanshi, S.; Gupta, S. A comprehensive study on the behavior of a novel bacterial strain Acinetobacter guillouiae for bioremediation of divalent copper. Bioprocess Biosyst. Eng. 2015, 38, 1749-1760. [CrossRef]

7. Oturan, M.A.; Aaron, J.J. Advanced oxidation processes in water/wastewater treatment: Principles and applications. A review. Crit. Rev. Environ. Sci. Technol. 2014, 44, 2577-2641. [CrossRef]

8. Krishnan, S.; Rawindran, H.; Sinnathambi, C.M.; Lim, J.W. Comparison of various advanced oxidation processes used in remediation of industrial wastewater laden with recalcitrant pollutants. IOP Conf. Ser. Mater. Sci. Eng. 2017, 206, 012089. [CrossRef] 
9. Al-Kdasi, A.; Idris, A.; Saed, K.; Guan, C.T. Treatment of textile wastewater by advanced oxidation processes-A review. Glob. Nest Int. J. 2004, 6, 222-230.

10. Hanela, S.; Durán, J.; Jacobo, S. Removal of iron-cyanide complexes from wastewaters by combined UV-ozone and modified zeolite treatment. J. Environ. Chem. Eng. 2015, 3, 1794-1801. [CrossRef]

11. Bes-Piá, A.; Mendoza-Roca, J.A.; Roig-Alcover, L.; Iborra-Clar, A.; Iborra-Clar, M.I.; Alcaina-Miranda, M.I. Comparison between nanofiltration and ozonation of biologically treated textile wastewater for its reuse in the industry. Desalination 2003, 157, 81-86. [CrossRef]

12. Deng, Y.; Zhao, R. Advanced Oxidation Processes (AOPs) in Wastewater Treatment. Curr. Pollut. Rep. 2015, 1, 167-176. [CrossRef]

13. Perkowski, J.; Kos, L. Decolouration of model dyehouse wastewater with advanced oxidation processes. Fibres Text. East. Eur. 2003, 11, 67-71.

14. Sharrer, M.J.; Summerfelt, S.T. Ozonation followed by ultraviolet irradiation provides effective bacteria inactivation in a freshwater recirculating system. Aquac. Eng. 2007, 37, 180-191. [CrossRef]

15. Chen, Z.; Fang, J.; Fan, C.; Shang, C. Oxidative degradation of N-Nitrosopyrrolidine by the ozone/UV process: Kinetics and pathways. Chemosphere 2016, 150, 731-739. [CrossRef] [PubMed]

16. Dai, Q.; Chen, L.; Chen, W.; Chen, J. Degradation and kinetics of phenoxyacetic acid in aqueous solution by ozonation. Sep. Purif. Technol. 2015, 142, 287-292. [CrossRef]

17. Litter, M.I.; Quici, N. Photochemical Advanced Oxidation Processes for Water and Wastewater Treatment. Recent Patents Eng. 2011, 4, 217-241. [CrossRef]

18. Badmus, M.A.O.; Audu, T.O.K.; Anyata, B.U. Removal of heavy metal from industrial wastewater using hydrogen peroxide. Afr. J. Biotechnol. 2007, 6, 238-242.

19. Aravinda, C.L.; Mayanna, S.M.; Muralidharan, V.S. Electrochemical behaviour of alkaline copper complexes. J. Chem. Sci. 2000, 112, 543-550. [CrossRef]

20. Chand Mali, S.; Raj, S.; Trivedi, R. Biosynthesis of copper oxide nanoparticles using Enicostemma axillare (Lam.) leaf extract. Biochem. Biophys. Reports 2019, 20, 100699. [CrossRef]

21. Martí, I.; Ferrer, A.; Escorihuela, J.; Burguete, M.I.; Luis, S.V. Copper(II) complexes of bis(amino amide) ligands: Effect of changes in the amino acid residue. Dalt. Trans. 2012, 41, 6764-6776. [CrossRef]

22. Jin, F.; Wei, M.; Liu, C.; Ma, Y. The mechanism for the formation of $\mathrm{OH}$ radicals in condensed-phase water under ultraviolet irradiation. Phys. Chem. Chem. Phys. 2017, 19, 21453-21460. [CrossRef] [PubMed]

23. Attri, P.; Kim, Y.H.; Park, D.H.; Park, J.H.; Hong, Y.J.; Uhm, H.S.; Kim, K.N.; Fridman, A.; Choi, E.H. Generation mechanism of hydroxyl radical species and its lifetime prediction during the plasma-initiated ultraviolet (UV) photolysis. Sci. Rep. 2015, 5, 9332. [CrossRef] [PubMed]

24. Ren, G.; Sun, D.; Chung, J.S. Kinetics study on photochemical oxidation of polyacrylamide by ozone combined with hydrogen peroxide and ultraviolet radiation. J. Environ. Sci. 2006, 18, 660-664.

25. Shi, L.B.; Tang, P.F.; Zhang, W.; Zhao, Y.P.; Zhang, L.C.; Zhang, H. Green synthesis of CuO nanoparticles using Cassia auriculata leaf extract and in vitro evaluation of their biocompatibility with rheumatoid arthritis macrophages (RAW 264.7). Trop. J. Pharm. Res. 2017, 16, 185-192. [CrossRef]

26. Etefagh, R.; Azhir, E.; Shahtahmasebi, N. Synthesis of CuO nanoparticles and fabrication of nanostructural layer biosensors for detecting Aspergillus niger fungi. Sci. Iran. 2013, 20, 1055-1058.

27. Lanje, A.S.; Sharma, S.J.; Pode, R.B.; Ningthoujam, R.S. Synthesis and optical characterization of copper oxide nanoparticles. Adv. Appl. Sci. Res. 2010, 1, 36-40.

28. Manyasree, D.; Peddi, K.M.; Ravikumar, R. CuO nanoparticles: Synthesis, characterization and their bactericidal efficacy. Int. J. Appl. Pharm. 2017, 9, 71-74.

29. Zhu, G.; Sun, Q.; Wang, C.; Yang, Z.; Xue, Q. Removal of Sulfamethoxazole, Sulfathiazole and Sulfamethazine in their Mixed Solution by $\mathrm{UV} / \mathrm{H}_{2} \mathrm{O}_{2}$ Process. Int. J. Environ. Res. Public Health 2019, 16, 1797. [CrossRef]

30. Hassaan, M.A.; El Nemr, A.; Madkour, F.F. Application of Ozonation and UV assisted Ozonation for Decolorization of Direct Yellow 50 in Sea water. The Pharmaceutical and Chemical Journal. 2016, 3, 131-138.

31. Dai, C.; Zhou, X.; Zhang, Y.; Duan, Y.; Qiang, Z.; Zhang, T.C. Comparative study of the degradation of carbamazepine in water by advanced oxidation processes. Environ. Technol. 2012, 33, 1101-1109. [CrossRef]

32. Jing, Z.; Cao, S.; Yu, T.; Hu, J. Degradation Characteristics of Aniline with Ozonation and Subsequent Treatment Analysis. J. Chem. 2015, 2015, 1-6. [CrossRef]

33. Wang, Z.; Li, J.; Song, W.; Zhang, X.; Song, J. Decomplexation of electroplating wastewater by ozone-based advanced oxidation process. Water Sci. Technol. 2019, 79, 589-596. [CrossRef] [PubMed] 
34. Guo, W.; Yang, Z.; Du, J.; Yin, R.; Zhou, X.; Jin, S.; Ren, N. Degradation of sulfadiazine in water by a UV/O 3 process: Performance and degradation pathway. RSC Adv. 2016, 6, 57138-57143. [CrossRef]

35. Barakat, M.A. New trends in removing heavy metals from industrial wastewater. Arab. J. Chem. 2011, 4, 361-377. [CrossRef]

36. Summerfelt, S.T. Ozonation and UV irradiation-An introduction and examples of current applications. Aquac. Eng. 2003, 28, 21-36. [CrossRef]

37. Khan, S.; Sayed, M.; Sohail, M.; Shah, L.A.; Raja, M.A. Advanced Oxidation and Reduction Processes. In Advances in Water Purification Techniques; Ahuja, S., Ed.; Elsevier Inc.: Amsterdam, The Netherlands, 2019; pp. 135-164. ISBN 9780128147917.

38. Hassaan, M.A.; El Nemr, A.; Madkour, F.F. Advanced oxidation processes of Mordant Violet 40 dye in freshwater and seawater. Egypt. J. Aquat. Res. 2017, 43, 1-9. [CrossRef]

39. Muniyasamy, A.; Sivaporul, G.; Gopinath, A.; Lakshmanan, R.; Altaee, A.; Achary, A.; Velayudhaperumal Chellam, P. Process development for the degradation of textile azo dyes (mono-, di-, poly-) by advanced oxidation process - Ozonation: Experimental \& partial derivative modelling approach. J. Environ. Manag. 2020, 265, 110397.

40. Colindres, P.; Yee-Madeira, H.; Reguera, E. Removal of Reactive Black 5 from aqueous solution by ozone for water reuse in textile dyeing processes. Desalination 2010, 258, 154-158. [CrossRef]

41. Zhang, F.; Yediler, A.; Liang, X.; Kettrup, A. Effects of dye additives on the ozonation process and oxidation by-products: A comparative study using hydrolyzed C.I. Reactive Red 120. Dye. Pigment. 2004, 60, 1-7. [CrossRef]

42. Hassaan, M.A.; El Nemr, A.; Madkour, F.F. Testing the advanced oxidation processes on the degradation of Direct Blue 86 dye in wastewater. Egypt. J. Aquat. Res. 2017, 43, 11-19. [CrossRef]

43. Munter, R. Advanced Oxidation Processes-Current Status and Prospects. In Proceeding of the Estonian Academy Sciences, Tartu, Estonia, 1 January 2001; pp. 59-80.

44. Khan, R.; Inam, M.A.; Zam Zam, S.; Akram, M.; Shin, S.; Yeom, I.T. Coagulation and Dissolution of CuO Nanoparticles in the Presence of Dissolved Organic Matter under Different pH Values. Sustainability 2019, 11, 2825. [CrossRef]

45. Al-Shannag, M.; Al-Qodah, Z.; Bani-Melhem, K.; Qtaishat, M.R.; Alkasrawi, M. Heavy metal ions removal from metal plating wastewater using electrocoagulation: Kinetic study and process performance. Chem. Eng. J. 2015, 260, 749-756. [CrossRef]

46. Chen, X.; Ren, P.; Li, T.; Trembly, J.P.; Liu, X. Zinc removal from model wastewater by electrocoagulation: Processing, kinetics and mechanism. Chem. Eng. J. 2018, 349, 358-367. [CrossRef]

47. Vasudevan, S.; Lakshmi, J. Process conditions and kinetics for the removal of copper from water by electrocoagulation. Environ. Eng. Sci. 2012, 29, 563-572. [CrossRef]

48. Khattab, I.A.; Shaffei, M.F.; Shaaban, N.A.; Hussein, H.S.; Abd El-Rehim, S.S. Study the kinetics of electrochemical removal of copper from dilute solutions using packed bed electrode. Egypt. J. Pet. 2014, 23, 93-103. [CrossRef]

49. Prasetyaningrum, A.; Widayat, W.; Jos, B.; Dharmawan, Y.; Ratnawati, R. UV Irradiation and Ozone Treatment of K-Carrageenan: Kinetics and Products Characteristics. Bull. Chem. React. Eng. Catal. 2020, 15, 319-330. [CrossRef]

50. Muruganandham, M.; Suri, R.P.S.; Jafari, S.; Sillanpää, M.; Lee, G.-J.; Wu, J.J.; Swaminathan, M. Recent Developments in Homogeneous Advanced Oxidation Processes for Water and Wastewater Treatment. Int. J. Photoenergy 2014, 2014, 821674. [CrossRef]

51. Asghar, A.; Raman, A.A.A.; Daud, W.M.A.W. Advanced oxidation processes for in-situ production of hydrogen peroxide/hydroxyl radical for textile wastewater treatment: A review. J. Clean. Prod. 2015, 87, 826-838. [CrossRef]

(C) 2020 by the authors. Licensee MDPI, Basel, Switzerland. This article is an open access article distributed under the terms and conditions of the Creative Commons Attribution (CC BY) license (http://creativecommons.org/licenses/by/4.0/). 